\title{
SOUTHERN APPALACHIAN HANDICRAFT INDUSTRY: IMPLICATIONS FOR REGIONAL ECONOMIC DEVELOPMENT
}

\author{
H. Max Miller, E. Evan Brown, and Terence J. Centner*
}

This study is based on data obtained in a survey of Southern Appalachian craftspeople and provides information on occupational entry, occupational involvement, and economic impact as well as the legal ramifications of participation by members of the handicraft industry. Due to the exploratory nature of the study, a descriptive level of analysis is employed in the examination of primary research variables. On the basis of this analysis it is concluded that occupational entry is not bound by apprenticeship roles or culturally transmitted folkways of knowledge, and that the level of involvement in craft production can be conditioned by a knowledge of, or participation in, support mechanisms that exist at the local level. Information presented in the analysis also points out that the independence of craftspeople does not isolate them from the various state and federal regulations concerning the regulation of employment. The implications for economic development are examined and a paradigm of development involving specialized industries is presented.

\section{Introduction}

Relatively little is known about America's handicraft industry in general and even less in particular. There is little understanding of its economic impact, its occupational structure, the legal implication of occupational involvement, or its size and scope. This paper is based on data which open a window to this little known and understood industry.

Although there has been a crafts industry in Southern Appalachia for more than 150 years, few studies have been undertaken to examine

\footnotetext{
*Associate Professor, Departments of Sociology and Agricultural Economics; Professor, Department of Agricultural Economics; and Assistant Professor, Department of Agricultural Economics, respectively, at the University of Georgia. The research reported here was supported by Experiment Station Project H-802, Department of Agricultural Economics, University of Georgia. The full report is available as Research Project No. 483, Agricultural Experiment Station, University of Georgia, Athens, GA 30602.
}

the impact of this industry on the economic structure of the region. Allen Eaton's classic work in 1937, Handicrafts of the Southern Highlands, sought to identify crafts and craftsmen in 235 counties in Southern Appalachia. He wanted to expose the Southern crafts industry to the larger national market. Stepp and Rowland (1944) studied family craft industries in South Carolina and concluded that various commodities, e.g., pottery, brooms, baskets, furniture, implements and syrups, were produced for sale prior to the Civil War. Initially these products were sold locally, but in time the marketing strategy evolved from a simple, at-site exchange to a system of national distribution and sale.

There was substantial interest in the crafts industry at the University of Tennessee during the 1950 s. Five masters' theses were directed at the crafts industries in eastern Tennessee (Hodges, 1951), southern Indiana (Stevens, 1951), North Carolina (Arnold, 1952), northeastern Oklahoma (Lombardi, 1953) and the Arkansas Ozark region (Mifflin, 1961). A common thread found in these studies was the importance of craft cooperatives and guilds on production standards and marketing practices.

McCulley (1968) studied the training, motives and problems of craftsmen in 10 eastern Tennessee counties. She found that most craftsmen received vocational counseling and vocational training in formal institutions, i.e., high school, community college, or university. People in the crafts industry used the production of their commodities as a recreational, as well as an income-producing activity. Although there was a market for craft commodities in that region, many producers were not aware of the opportunities available to them. McCulley recommended that efforts should be made to inform craftsmen of potential markets, as craft production could be used to augment income in low income areas.

More than 10 years later (1979) the Appalachian Crafts Project published a comprehensive program of more than 350 festivals, exhibitions and galleries available to the Appalachian crafts industry. The program was an 
important marketing tool for craftsmen from Connecticut to Florida and from Missouri to the Carolinas. Although highly descriptive, none of the research into the crafts industry is analytical. It is this shortcoming that this paper addresses.

During October and November of 1983 , lists of handicraft producers were obtained from two cooperatives operating about 10 independent retail craft outlets, as well as the Southern Highland Handicraft Guild, John C. Campbell Folk School and Penland School. All of these craft-related organizations are located in north Georgia and western North Carolina. Twenty-five interviews with craftspeople were conducted and 1,500 additional names and addresses of craft producers were obtained. Questionnaires were mailed in March to 600 individuals out of the 1,500 known names and addresses. These 600 individuals had mailing addresses in the mountain area of northern Georgia and the adjacent area of western North Carolina. From the 600 mail-outs, 266 questionnaires were returned. Of these, 235 were completely or nearly completely filled out by the individual craftsperson so that they could be used for analysis. Thirty-one returned questionnaires were unusable. The majority of these were returned by the surviving spouse of a deceased craftsperson. Some were returned because of incorrect or no known address while a few were returned with the notation that they never gave out information. The 235 usable questionnaires and the 25 obtained by personal interview totaled 260 respondents.

Since a random sample of the total population of craftspeople in the United States was not, could not, and cannot be obtained, data in this paper cannot be generalized to represent all craftspeople in the United States. Whether the 260 cooperating craftspeople are representative of all craftspeople in the geographic area studied is not known. Members of some guilds, marketing cooperatives, independent local retail craft outlets and craft schools may or may not be over represented in the data obtained.

\section{General Characteristics}

The 260 craftspeople had resided in either North Carolina or Georgia an average of $\mathbf{2 5 . 2}$ years. The median number of years was 38.0, indicating an influx of new craftspeople in recent years. For example, 102 individuals or 39.1 percent had been area residents for 10 years or less. This supports the expressed opinion of many craftspeople that the area is widely known for craft production and that craftpeople are moving in to be near individuals with similar interests.

Of 257 respondents who listed ethnic backgrounds, 252 listed themselves as white, four as American Indian and one as Hispanic. Two hundred thirty-five (91.4 percent) reported they were head or joint-head of a household while 22 (8.6 percent) said they were not. One hundred twenty-one (46.7 percent) of the households had two members. The average number of members per household was 2.6. Thirty-nine percent of the 260 craftspeople were males, and among the 97 individuals devoting full-time to their craft, almost half (48 out of 97) were males.

Table 1

Where or How Full-time and Part-time Craftspeople Obtained Their Craft Training

\begin{tabular}{|c|c|c|c|c|}
\hline \multirow{2}{*}{$\begin{array}{c}\text { Where Craft Training } \\
\text { Was Obtained }\end{array}$} & \multicolumn{2}{|c|}{ Full-time } & \multicolumn{2}{|c|}{ Part-time } \\
\hline & Number & Percent & Number & Percent \\
\hline College or university course(s) & 37 & 38.2 & 48 & 30.0 \\
\hline Workshops, seminars, local classes & 6 & 6.2 & 10 & 6.3 \\
\hline Penland School & 12 & 12.4 & 9 & 5.6 \\
\hline Haywood Technical School & 3 & 3.1 & 8 & 5.0 \\
\hline Campbell Folk School & 4 & 4.1 & 5 & 3.1 \\
\hline Apprenticeship & 4 & 4.1 & 5 & 3.1 \\
\hline Self-taught & 19 & 19.6 & 48 & 30.0 \\
\hline Learned from friends, relatives & 8 & 8.2 & 17 & 10.6 \\
\hline Father, mother, grandparents & 3 & 3.1 & 7 & 4.4 \\
\hline Learned from publications & 1 & 1.0 & 3 & 1.9 \\
\hline Totals & 97 & 100.0 & $160^{*}$ & 100.0 \\
\hline
\end{tabular}

*Three did not specify source of training. 
Educational achievement of the 254 respondents was very high. Seventy-three percent of this total number had formal education beyond the high school level, and the majority of these had a college degree or an advanced college degree. The average number of years of formal education completed was 14.2 These findings are contrary to the popular belief of many Americans that handicraft people are generally little old ladies, uneducated and producing traditional family crafts.

\section{Occupational Entry}

In response to the question of where respondents secured training for their craft, nearly one half said that training was obtained from a course or courses taken at college or from schooling beyond the high school level. This response further substantiates educational attainment as reported by respondents in the survey.

Table 1 presents information on where fulltime or part-time craftspeople had obtained their craft training. Less than 11.0 percent were producers of a traditional family craft and only about one in four was even influenced by a family member in their choice of a craft. Apparently, the individual or organization most influential in the craftsperson's training was a classroom instructor. Only 17.0 percent of all respondents said they obtained their crafts training from a family member. It is interesting to note, however, that 30.0 percent, or ap- proximately one-third, of the part-time producers were "self-taught," while only 19.6 percent, or one-fifth of the full-time producers, were "self-taught."

In an effort to obtain information on the acquisition of skills and knowledge for entry into a craft-related occupation, respondents were presented with the question of how and/or why they got into craftwork. The information contained in Table 2 represents a classification of responses of the total sample of full- and parttime producers to this question. As an openended question that did not offer the option of categorical choices, respondents had the opportunity to give as much information as they felt appropriate or relevant in their reply to the question. Although a broad range of "reasons" for getting into craftwork was given by both full- and part-time craftworkers, individual responses tended to be highly concise and to the point.

More than any other single reason given for getting into craftwork, both full- and part-time producers reported that it was because of a "personal interest in a particular craft item(s)." Responses indicating a "personal interest in a craft" could be expanded to include other responses such as "through a college course or courses," "through specialized classes or workshops," "teaching crafts," or "serving as an apprentice." Taken all together, this category of response accounts for 63.2 percent of the full-time and 52.5 percent of the part-time producers. Turning to craft production as a "hobby," both before and after retire-

Table 2

How and Why Full-time and Part-time Handicraft Producers Began Making and Selling Crafts

\begin{tabular}{|c|c|c|c|c|}
\hline \multirow{2}{*}{$\begin{array}{c}\text { Reason for Beginning } \\
\text { Craft Production }\end{array}$} & \multicolumn{2}{|c|}{ Full-time } & \multicolumn{2}{|c|}{ Part-time } \\
\hline & Number & Percent & Number & Percent \\
\hline Hobby (before or after retirement) & 7 & 7.4 & 33 & 20.4 \\
\hline Needed more income & 10 & 10.5 & 5 & 3.1 \\
\hline Interest in crafts & 26 & 27.4 & 56 & 34.6 \\
\hline To pass time & - & - & 3 & 1.8 \\
\hline Teaching crafts & 3 & 3.2 & 6 & 3.7 \\
\hline Made it for my own use & 1 & 1.1 & 4 & 2.5 \\
\hline Through friends or relatives & 6 & 6.3 & 13 & 8.0 \\
\hline Traditional family craft & 10 & 10.5 & 17 & 10.5 \\
\hline Handicapped, turned to crafts & 1 & 1.1 & 2 & 1.2 \\
\hline Through college course or courses & 17 & 17.9 & 9 & 5.6 \\
\hline Specialized class & 14 & 14.7 & 13 & 8.0 \\
\hline Apprenticeship & - & - & 1 & .6 \\
\hline Totals & $95^{*}$ & 100.0 & $162^{* *}$ & 100.0 \\
\hline
\end{tabular}

*Two full-time producers did not reply

**One part-time producer did not reply 
ment, was a response category that accounted for 16.0 percent of all respondents, although getting into a craftwork through a hobby was offered as a reason for getting into crafts more often by part-time producers (20.4 percent) than by full-time producers (7.4 percent).

\section{Legal Restrictions Affecting Workers Employed in the Home}

Sixty-one percent of the full-time and 21.0 percent of the part-time craft producers had at least one other person working with them on a full- or part-time basis. On the basis of numbers of workers involved in craft production, legal problems which may confront those who earn part or all of their income from working on, or manufacturing, handicrafts in their homes become highly relevant. The Fair Labor Standards Act (29 U.S.C., section 201 et seq.) generally provides rules protecting employees from unfair labor practices, including minimum wages, overtime pay and regulation of the employment of minors. This act applies to craftspeople in that those who sell some of their crafts at fairs, conventions or exhibitions in other states would be involved in the sale of goods in interstate commerce. Furthermore, if the expected buyers at the retail shop are from other states or the crafts are sold to a buyer who at some point is likely to resell the goods in another state, the craftsperson will be deemed to be engaged in interstate commerce and is within the scope of the FLSA.

Although the FLSA was enacted more than 40 years ago, questions remain concerning its coverage. One of these questions is whether the FLSA applies to craft workers employed in their homes who market their crafts through a business organization, including a cooperative. The survey disclosed that 24 percent of the craftspeople marketed some of their crafts through a cooperative, guild, or retail store. Does this business arrangement subject the buyer and the craft workers to the restrictions of the FLSA?

The FLSA applies to employment situations where there exist an employer and an employee. In contrast, if the craftsperson is an independent contractor, there is no employment arrangement. Thus, the judiciary has analyzed business arrangements to determine whether they are more analogous to an employment arrangement or an independent contractor.
It may be argued that businesses which purchase handicrafts from craftspeople use a contractual arrangement whereby the craftspeople retain their independent contractor status. However, craftspeople will not be considered to be independent contractors by virtue of a contractual agreement covering the sale of their crafts. Judicial decisions have found that cooperative members and independent seamstresses selling their crafts pursuant to agreements with cooperatives and corporations were employees within the scope of the FLSA. The issue is the dependence of the craftspeople upon the buyer. Any person who is dependent upon a buyer for the sale of homemade crafts will be considered to be an employee governed by the FLSA.

The survey disclosed that 49 percent of the craftspeople felt they could increase productivity through apprentices, but only 26 percent expressed a willingness to employ an apprentice. However, 64 percent of the respondents were willing to teach their craft for pay. These data suggest that part of the reluctance to employ an apprentice presumably arises because it is not profitable. One reason for this situation may be the federal minimum wage law; section 6 of the FLSA currently requires employers to pay employees at least $\$ 3.35$ an hour. The difficulty in mastering certain crafts may mean that apprentices require months or years of training before they are able to produce crafts at a sufficient rate and of sufficient quality to justify payment of the minimum wage.

In response to industry demand, the federal government has adopted regulations providing for the employment of apprentices at wages below the minimum wage. It is not clear, however, that the apprentice regulations facilitate the employment of apprentices by craftspeople. The provisions only apply to skilled trades with characteristics enumerated in the regulations, including the requirement that one year or more of work experience is needed to learn the trade. The provisions re quire the appointment of a joint apprentice committee representative of employers and employees to direct the training and the issuance of a certificate. The certificate must set forth conditions and limitations including the subminimum wage rates. In addition, the employer must keep records. Even if craftspeople were aware of these organizational and 
paperwork requirements, the requirements may be too burdensome to offer a viable alternative for the employment of an apprentice.

\section{Occupational Involvement}

Information concerning knowledge of, and involvement in, craft related organizations, guilds, or associations was obtained from survey respondents. Data concerning the knowledge of reference groups along with participation in these organizations by craftworkers provides information on important reference groups and support systems necessary for continued involvement in craft occupations. The nature and extent of involvement in occupationally related organizations can be viewed as an indicator of the strength and development of the craft(s) industry in north Georgia and western North Carolina.

Table 3 shows the rankings of the craft organizations by the craftspeople, who were asked to name the three groups best known to them. The Southern Highland Handicraft Guild received the largest number of respondents (37) ranking as first place from among the full-time craft people. Maco-crafts received the most "first place" rankings (45) by the part-time producers in the sample. More part-time craft producers in the sample ranked the Southern Highland Handicraft Guild as the "best known" than did the full-time producers (a total of $\mathbf{4 3}$ part-time craftspeople as compared to 37 full-time). This Highland Guild was mentioned as one of the three best known craft organizations the highest total number of times by both the full-time and part-time respondents in the sample. Other organizations that were well known were: the American Craft Council, the Piedmont Craftsman and High Country Crafters.

Table 4 provides information concerning craft related organizations in which sample

Table 3

The Three Best Known Craft Organizations by Sample Respondents

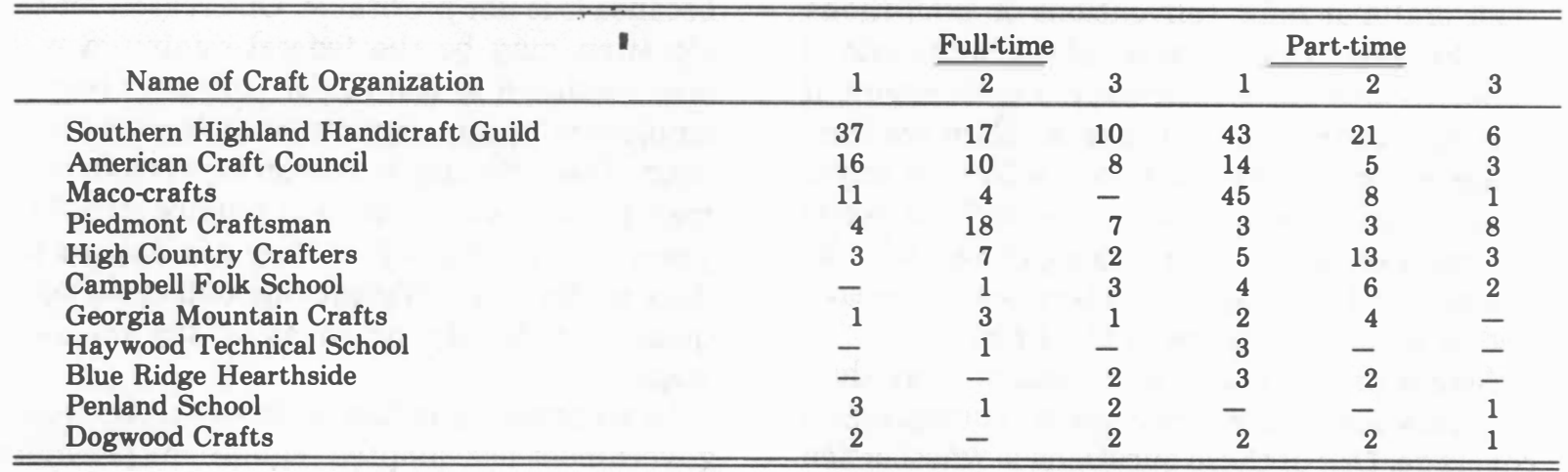

Table 4

Membership in Craft-related Organizations by Sample Respondents

\begin{tabular}{lcc}
\hline \hline Craft Related Organization & Full-time & Part-time \\
\hline Southern Highland Handicraft Guild & 38 & 42 \\
High Country Crafters & 11 & 14 \\
Maco-crafts & 52 & 13 \\
Various fiber \& weaving guilds & 37 & 36 \\
Southern Appalachia Metal Workers & 11 & 1 \\
Woodworkers Guilds & 2 & 1 \\
Blue Ridge Hearthside Crafts & 4 & 8 \\
American Crafts Council & 4 & 4 \\
Other craft guilds & 5 & 1 \\
Indian Arts and Crafts Guilds & 1 & - \\
Hendersonville Co. Crafts & - & 5 \\
Old Depot, Black Mt. & - & 1 \\
Georgia Mountain Crafts & - & 2 \\
Piedmont Craftsmen & & \\
\hline \hline
\end{tabular}


respondents have membership. The Southern Highland Handicraft Guild was the organization in which most respondents (both part-time and full-time) held membership. When categorized as full-time and part-time producers, more full-time producers (42) belonged to the Southern Highland Handicraft Guild than any other single organization, and more part-time producers were members of Maco-Crafts (52) than any other organization. Both full-time (36) and part-time (37) craft producers had a high level of membership in various fiber and weaving guilds. High Country Crafters and the American Crafts Council were listed by both full-time and part-time craft producers as being organizations of membership.

\section{Financial Analysis}

To obtain meaningful analysis, the crafts- people responding to the survey were grouped into nine classifications. These were: jewelry, paintings, metals, woodcarving, furniture, pottery, fabrics, leather and other. Individuals in these nine classifications were further subdivided into full- and part-time producers. This permitted comparisons of earnings per hour of input into production of their own craft item or items by craft classification and by full- and part-time status. The results of these groupings revealed surprising information. For example, full-time jewelry craftspeople earned $\$ 13.22$ per hour of input into their craft, while full-time fabrics craftspeople earned $\$ 3.27$ per hour (Table 5). For eight of the nine craft classifications, full-time craftspeople earned more per hour than did the part-time people. The one exception was leather. However, in this classification there were only two parttime craftspeople and one of these individuals

Table 5

Earnings of Full- and Part-Time Craftspeople Per Hour, Number of Hours Worked Daily and Net Incomes by Type of Craft Categories

\begin{tabular}{|c|c|c|c|c|c|}
\hline Category & $\begin{array}{c}\text { Earnings } \\
\text { Per } \\
\text { Hour }\end{array}$ & $\begin{array}{c}\text { Hours } \\
\text { Worked } \\
\text { Daily }\end{array}$ & $\begin{array}{c}\text { Yearly } \\
\text { Income } \\
\text { From } \\
\text { Own } \\
\text { Craft }\end{array}$ & $\begin{array}{c}\text { Yearly } \\
\text { Income } \\
\text { From Craft } \\
\text { Related } \\
\text { Activities }\end{array}$ & $\begin{array}{l}\text { Total } \\
\text { Craft } \\
\text { Yearly } \\
\text { Income }\end{array}$ \\
\hline \multicolumn{6}{|l|}{ Jewelry } \\
\hline Full-time & 13.22 & 7.4 & 24,458 & 5,117 & 29,575 \\
\hline Part-time & 4.20 & 4.2 & 4,407 & 1,302 & 5,709 \\
\hline \multicolumn{6}{|l|}{ Paintings } \\
\hline Full-time & 5.81 & 8.4 & 12,200 & 3,789 & 15,989 \\
\hline Part-time & 4.29 & 3.0 & 3,215 & 253 & 3,468 \\
\hline \multicolumn{6}{|l|}{ Metals } \\
\hline Full-time & 7.67 & 8.0 & 15,330 & 281 & 15,611 \\
\hline Part-time & 6.00 & 2.5 & 3,750 & 863 & 5,709 \\
\hline \multicolumn{6}{|l|}{ Woodcarving } \\
\hline Full-time & 5.80 & 9.4 & 13,620 & 1,233 & 14,853 \\
\hline Part-time & 3.12 & 2.6 & 2,030 & 149 & 2,179 \\
\hline \multicolumn{6}{|l|}{ Furniture } \\
\hline Full-time & 8.57 & 6.5 & 13,920 & 284 & 14,204 \\
\hline Part-time & 2.35 & 1.8 & 1,059 & 142 & 1,201 \\
\hline \multicolumn{6}{|l|}{ Pottery } \\
\hline Full-time & 5.67 & 8.1 & 11,485 & 758 & 12,243 \\
\hline Part-time & 5.40 & 3.9 & 5,261 & 8,881 & 14,142 \\
\hline \multicolumn{6}{|l|}{ Fabrics } \\
\hline Full-time & 3.27 & 10.3 & 8,422 & 1,476 & 9,898 \\
\hline Part-time & 2.22 & 2.6 & 1,443 & 282 & 1,725 \\
\hline \multicolumn{6}{|l|}{ Leather } \\
\hline Full-time & 3.51 & 9.7 & 8,500 & 447 & 8,947 \\
\hline Part-time & 17.37 & 1.9 & 8,250 & -- & 8,250 \\
\hline \multicolumn{6}{|l|}{ Other } \\
\hline Full-time & 4.08 & 7.9 & 8,059 & 507 & 8,566 \\
\hline Part-time & 4.01 & 2.4 & 2,405 & 337 & 2,742 \\
\hline \multicolumn{6}{|l|}{ Total Averages } \\
\hline Full-time & 5.57 & 8.7 & 12,112 & 1,407 & 13,519 \\
\hline Part-time & 3.58 & 2.7 & 2,417 & 489 & 2,906 \\
\hline
\end{tabular}


had created a unique item that could be produced quickly and was in strong demand.

The yearly income for full-time craftspeople from the production of their own craft averaged $\$ 12,112$ and ranged from $\$ 24,458$ for those in the jewelry classification down to $\$ 8,059$ for the others classification. For parttime producers, income from their own craft averaged $\$ 2,417$, ranging from $\$ 8,250$ for leather to $\$ 1,059$ for furniture.

Incomes from craft-related activities, such as instruction, selling other people's crafts, selling raw materials and supplies, instruction kits, publications and honorariums were very important for some types of craft classifications and very minor for others. Incomes from these other sources averaged $\$ 1,407$ for fulltime craftspeople, ranging from $\$ 5,117$ for jewelry down to $\$ 281$ for metals. Incomes from these other sources were significantly more important in proportion to income from their own craft production for part-time craftspeople. This accounts for nearly 17 percent of total craft incomes for the average part-time person and ranges from 62.8 percent for part-time potters to 0 for leather workers (Table 5).

Because of the relatively high income from craft-related activities of part-time potters $(\$ 8,881)$, their total annual craft income was greater than that of full-time potters, who essentially were producers, not teachers. Total yearly income from their craft for part-time potters was $\$ 14,142$ compared to $\$ 12,243$ for full-time potters. Apparently, this anomaly is due to the relatively large investment in kilns and equipment required for pottery production which forces them to work full-time at the craft in order to justify the expense or, for those who may not have sufficient time to devote to production, encourages them to offer instruction, which in turn results in additional income from the sale of raw materials, supplies, student craft production and honorariums.

While craft and craft-related incomes of some full-time producers may appear low, it is important to note that these individuals, their spouses and other members of individual families do not rely on one source of income, any more than does the average non-craft family. Earned incomes of spouses, children and/or other members of the family were not obtained, nor incomes from pensions, social security, rents, dividends, interest payments, etc.

\section{Potential Role of Specialized Industries in Economic Development}

The implications for economic development, based on the findings of this study, are quite profound and have the potential of producing an enormous impact in economically declining rural areas. Inferences and generalizations regarding development must take into account, however, the highly localized and specialized nature of the crafts industry. The production of crafts and the growth of this economic activity in northeast Georgia and western North Carolina is a specialized occupational activity to which local circumstances give a particular advantage. A pronounced cultural and historical background that diffuses an aura of quaintness and folk wisdom (whether it exists or not) provides an unusual catalyst for craft production and marketing. Other factors related to environment and scenic attractions, as well as tourism, must be taken into account in explaining the growth of the craft industry in this particular geographical area.

At this point in this discourse on development, an examination of the potential role of specialized industries in promoting economic growth is warranted. The brief historical and cultural perspective given in the preceding chapter opens the gate to a conceptual model that must also be included. An essential question becomes the one which asks: Is there a paradigm of development in which the emergence of the crafts industry in the geographic area of study is but an exemplar? Crafts, per se, represent the content of this study; the emergent form of development, however, differs from the content and can be generalized. The primary inference to be drawn from the findings of this study leads to the conclusion that specialized industries do have a potential role in the economic development of depressed and declining areas in the rural sector.

Craft production and marketing have grown and proliferated due to the right blend of circumstances involving a specific geographic and cultural context. Craft production as a specialized industry is not recommended for development purposes in other geographic areas with a totally different context. A specialized industry must fit into its context. It can't be inappropriate for its setting. Ex- 
amples of specialized industries that have economic impact and potential in other geographic areas are numerous. Vidalia onions and the production of related food items in the coastal plains area of Georgia, catfish farming in the Mobile Bay area of Alabama, or the heavy economic impact of the music industry in Tennessee (particularly the Nashville area), are examples of specialized industries that serve as an adjunct to the economic structure of specific geographic areas or regions. Many geographic areas have the potential for development of specialized industries and this form of development does provide a brighter promise for the future in economically depressed areas.

In generalizing the form of development it is necessary to consider first the characteristics of emergent specialized industries that may be suited to economic development purposes. Next, there must be a determination of the relationships among these characteristics, i.e., a determination of how unique characteristics can facilitate economic development. The form of development is still the same, the element that is unique is the content. Finally, cultural, historical and social conditions must be conducive to the development of these "specialized" industries and, as such, allow for the expansion of volume and quality control. From this perspective, leaders, planners and development specialists in local areas or regions might very well consider the potential role of specialized industries as an adjunct to economic development. Characteristics typically associated with production in specialized industries involve the following processes:

1. Highly specialized skills and knowledge that may not be easily transferred to other skills and industries.

2. People who have these skills or work to acquire them are more likely to move into this region and create a more viable work force in this specialized industry.

3. A larger support group for any occupational endeavor tends to create mechanisms for support within the group and more output for the marketing environment.

4. This engenders the movement from a less complex form to a more complex form of production marketing and distribution of highly specialized commodities.

The products of specialized industries (the content) also have a number of commonly shared characteristics that facilitate the marketing process. These characteristics are:

1. Some unique features of the commodity.

2. Social legitimacy of the commodity.

3. Aesthetic or functional attributes of the commodity.

4. A quality of commodity that is perceived as unusual or economically inflatable.

5. A personalized element of exchange that provides a psychological involvement with others in the exchange process.

Industries of a specialized nature need to be skill and labor intensive and must capitalize on local geographic and cultural resources. These factors constitute the basic ingredients for economic success in this production realm.

\section{Conclusions}

Some implications for the usage which can be made from data obtained during the study are immediately apparent. These include:

1. Entry into this occupational realm is not necessarily circumscribed by apprenticeship roles or culturally transmitted folkways of knowledge concerning the production of specific crafts in a localistic setting. Creative individuals who would be equally satisfied by engaging in more than one type of craft activity, and who are equally qualified to work in more than one craft or medium, will have an opportunity to make a selection of which particular craft would offer the best economic incentive.

2. Guidance can be offered in whether the individual should become involved on a part- or full-time basis at a particular craft. A knowledge of, and participation in, existing organizations or guilds serving the craft community is indicative of the existence of support mechanisms that can enhance occupational involvement.

3. For type of craft, for part- or full-time producers, guidance is available on how to market and where to market and what legal prescriptions apply to the marketing process. The independence of craftspeople does not isolate them from various state and federal regulations concerning the regulation of employment.

4. There is a paradigm of development that has implications for the study of specialized industries. 
5. Specialized industries have a potential role in economic development at the local level, but must fit within the context of local resources and circumstances.

\section{REFERENCES}

Appalachian Crafts Project. Georgia Crafts Appalachia. Georgia Council for the Arts and Humanities, 1979.

Arnold, Dorothy A. "Some Recent Contributions of the Cherokee Indians of North Carolina to the Crafts of the Southern Highlands" (unpublished Master's Thesis), The University of Tennessee, Knoxville, 1979.

Brooker, John K. and Merv J. Yetley. An Economic Analysis of the Marketing Sector of the Tennessee Craft Industry, Agricultural Experiment Station, University of Tennessee, Bulletin 578, June 1978.

Eaton, Allen H. Handicrafts of the Southern Highlands, Sage Foundation, 1937.

Ely, Gerald E. The Cooperative Approach to Crafts; Economics, Statistics and Cooperative Services, U.S.D.A., Program Aid No. 1001, Washington, D.C., April 1978.

Hodges, Sidney C. "Handicrafts in Sevier County, Ten- nessee" (unpublished Master's Thesis), The University of Tennessee, Knoxville, 1951.

Lombardi, Cesaro L. "A Survey of Northeastern Oklahoma Craftsmen and Their Work" (unpublished Master's Thesis), The University of Tennessee, Knoxville, 1953.

McCulley, Lou Ann. "A Survey of the Crafts and Craftsmen of Ten Upper East Tennessee Counties" (unpublished Master's Thesis), The University of Tennessee, Knoxville, 1968.

Mifflin, Betty. "A Survey of Contemporary Craftsmen in the Arkansas Ozark Region to Locate Craftsmen, Determine Their Work and Identify Problems in Craft Production" (unpublished Master's Thesis), The University of Tennessee, Knoxville, 1961.

Ritzer, George. Working: Conflict and Change, PrenticeHall, Inc., Chap. 3, 1977.

Stepp, J. M. \& Gil Rowland. Adventures in Small-Scale Rural Enterprises in South Carolina, Circular 67, South Carolina Agricultural Experiment Station: Clemson, S.C., 1944.

Stevens, Bernice A. "Contemporary Crafts and Craftsmen of Southern Indiana" (unpublished Master's Thesis), The University of Tennessee, Knoxville, 1951.

United States Code, Title 29, section 201 et seq., 1982.

Unknown. The Goodfellow Catalog of Wonderful Things, No. 3, Chilton Book Co., Radnor, Pa., 1983. 